University of Nebraska - Lincoln

DigitalCommons@University of Nebraska - Lincoln

Agronomy \& Horticulture -- Faculty Publications

Agronomy and Horticulture Department

1975

\title{
Influence of Seed Size, Planting Depth, and Companion Crop on Emergence and Vigor of Seedlings in Sweetclover
}

Francis A. Haskins

University of Nebraska-Lincoln, fhaskins@neb.rr.com

Herman J. Gorz

United States Department of Agriculture

Follow this and additional works at: https://digitalcommons.unl.edu/agronomyfacpub

Part of the Plant Sciences Commons

Haskins, Francis A. and Gorz, Herman J., "Influence of Seed Size, Planting Depth, and Companion Crop on Emergence and Vigor of Seedlings in Sweetclover" (1975). Agronomy \& Horticulture -- Faculty

Publications. 275.

https://digitalcommons.unl.edu/agronomyfacpub/275

This Article is brought to you for free and open access by the Agronomy and Horticulture Department at DigitalCommons@University of Nebraska - Lincoln. It has been accepted for inclusion in Agronomy \& Horticulture -Faculty Publications by an authorized administrator of DigitalCommons@University of Nebraska - Lincoln. 


\title{
Influence of Seed Size, Planting Depth, and Companion Crop on Emergence and Vigor of Seedlings in Sweetclover ${ }^{1}$
}

\author{
F. A. Haskins and H. J. Gorz ${ }^{2}$
}

\begin{abstract}
Seed size has been shown to have an important in. fluence on the emergence and early growth of seedlings of several forage legumes, but only fragmentary information on seed size effects in sweetclover (Melilotus spp.) has been published. Therefore, a 2-year study was conducted in which spring and fall seedings of small, medium, and large seeds of 'Madrid' and 'NI3' sweetclover (Meli. lotus officinalis (L.) Lam.) were made at depths of 19, 38 , and $57 \mathrm{~mm}$. The spring seeding also included a comparison of a companion crop (oats) with no companion crop. Data on emergence score and plant height were collected for the spring seeding only; stand count and dry matter yield of tops and roots were measured for both spring and fall seedings.

The companion crop had little effect on emergence score, but it reduced stand count and plant height, and was highly detrimental to dry matter yield. The performance of Madrid was poorer in all respects than that of N13, an experimental cultivar with relatively large seeds. As planting depth was increased, stand counts decreased, but the performance of plants that emerged from the greater depths was relatively good. The most striking results of increased seed size appeared to be improved emergence score and increased dry matter production.
\end{abstract}

Additional index words: Melilotus officinalis (L.) Lam., Top/root ratio.

S TUDIES of the relationship between seed size and $\mathcal{S}$ and plant performance date back many years. For example, in 1908 one of the papers published in Volume 1 of the Proceedings of the American Society of Agronomy reported the results of a study of seed size and yield in 12 farm crops (14). An even earlier report (7) presented the results of a preliminary survey of 35 legumes (including sweetclover, Melilotus spp.), in which seedlings from a small number of large and small seeds of each entry were compared. These early studies revealed that plants from large seeds were generally more vigorous than plants from small seeds of the same variety. Similarly, in his excellent 1959 review on seed size in forage legumes, Black (2) conclud-

${ }^{1}$ Contribution from the ARS-USDA, and the Nebraska Agric. Exp. Stn., Lincoln. Published as Paper No. 3904, Journal Series, Nebraska Agric. Exp. Stn. The authors gratefully acknowledge the help of Dr. Robert F. Mumm, Statistical Laboratory, Nebraska Agric. Exp. Stn. in the analysis of the data. Received Feb. 21, 1975 .

"Bert Rodgcrs Professor of Agronomy, Univ. of Nebraska, Lincoln, NE 68503; and Research Geneticist, ARS-USDA, Lincoln, Neb., respectively. ed that the accumulation of dry matter during early seedling growth is directly related to seed size, and that seed size limits the depth from which seedlings can emerge.

Seed size is of continuing interest to agronomists, as shown by recent reports on such diverse crops as wheat (Triticum aestivum L.) (9), soybeans (Glycine max (L.) Merr.) (3), and rapeseed (Brassica campestris L.) (1). Recent papers involving seed size of forage legumes include reports on alfalfa (Medicago sativa $\mathrm{L}$.) (4), birdsfoot trefoil (Lotus corniculatus L.) (4, 13), milkvetch (Astragalus spp.) (12), sainfoin (Onobrychis viciifolia Scop.) (4), white clover (Trifolium repens L.) (8), and red clover (Trifolium pratense L.) (5). All of these reports agree generally with the earlier observations in indicating that the performance of plants from large seeds was superior to that of plants from small seeds. A recent paper (10) indicates that sunflower (Helianthus annuus L.) departs from this general rule. In this instance, size of achenes planted had no significant effect on yield of achenes produced.

Except for the very early work already cited (7), no data on seed size and seedling vigor in sweetclover have been found in the literature. Because of this apparent paucity of published information on sweetclover, and because of the increased importance this crop could assume in the event of a continuing shortage of $\mathrm{N}$ fertilizer, we decided to complete the analysis of some data gathered at the Nebraska Agricultural Experiment Station in the early 1960 's, concerning the influence of seed size, planting depth, and companion crop on seedling vigor in sweetclover. The results of this analysis form the basis of this paper.

\section{MATERIALS AND METHODS}

Cultivars. 'Madrid' and 'NI3', both of which are cultivars of yellow-flowered biennial sweetclover (Melilotus officinalis (L.) Lam.), were used in this 2-year study. Madrid is a commercial cultivar originally introduced from Spain (11). N13 is an experimental cultivar selected from a large-seeded introduction (P.I. 178,985) from Turkey (6).

Seed Sizes. Hand screens were used to separate seeds of each cultivar into thrce size classes. Seed weights were then determined for each size class (Table 1). Seeds from the first screening were used for spring planting in both 1960 and 1961 and for fall planting in 1960. Newer seed lots of both cultivars were screened for the fall planting in 1961 .

Planting Procedure. Germination percentage was determined for each seed-size class for both cultivars, and these percentages 
Table 1. Mean weights of three size classes of Madrid and N13 sweet clover seeds.

\begin{tabular}{|c|c|c|c|c|}
\hline \multirow[b]{2}{*}{ Variety } & \multirow{2}{*}{$\begin{array}{l}\text { Size } \\
\text { class }\end{array}$} & \multicolumn{3}{|c|}{ Seed weight* } \\
\hline & & First screening ${ }^{\dagger}$ & Second & d screening + \\
\hline & & $-\mathrm{mg} / 1$ & seeds & \\
\hline \multirow[t]{3}{*}{ Madrid } & Small & 150 & & 150 \\
\hline & Medium & 211 & & 180 \\
\hline & Large & 259 & & 221 \\
\hline \multirow{3}{*}{$\mathrm{N} 13$} & Small & 256 & & 233 \\
\hline & Medium & 396 & & 392 \\
\hline & Large & 530 & & 514 \\
\hline
\end{tabular}

* Each figure represents the mean of four determinations.
the spring and fall of 1960 and the spring of 1961 . the spr
1961.

Table 2. Dates of planting and data collection.

\begin{tabular}{|c|c|c|c|}
\hline \multirow{2}{*}{$\begin{array}{l}\text { Planting or } \\
\text { observation }\end{array}$} & \multicolumn{3}{|c|}{ Date in } \\
\hline & & 1960 & $1961^{*}$ \\
\hline \multicolumn{4}{|l|}{ Spring seeding } \\
\hline $\begin{array}{l}\text { Oats planted } \\
\text { Sweetclover planted } \\
\text { Emergence scored } \\
\text { Stands counted } \\
\text { Height measured } \\
\text { Plants harvested }\end{array}$ & 14 June, & $\begin{array}{l}25 \mathrm{Apr} . \\
10 \mathrm{May} \\
17 \text { May } \\
28 \text { May } \\
28 \text { June } \\
28 \text { June. } 12 \text { July }\end{array}$ & $\begin{array}{c}\text { 18 Apr. } \\
24 \text { Apr. } \\
8 \text { May } \\
22 \text { May } \\
29 \text { May } \\
29 \text { May, } 12 \text { June, } 26 \text { June }\end{array}$ \\
\hline \multicolumn{4}{|l|}{ Fall seeding } \\
\hline $\begin{array}{l}\text { Sweetclover planted } \\
\text { Stands counted } \\
\text { Plants harvested }\end{array}$ & 6 Sept. , & $\begin{array}{l}10 \text { Aug. } \\
26 \text { Aug. } \\
20 \text { Sept. , } 4 \text { Oct. }\end{array}$ & $\begin{array}{l}14 \text { Aug. } \\
9 \text { Sept. } \\
21 \text { Sept. , } 5 \text { Oct., } 19 \text { Oct. }\end{array}$ \\
\hline
\end{tabular}

* Data were not complete for $26 \mathrm{~J}$ une 61 harvest. Therefore, the combined analysis for spring seeding is based on only the first two harvests in both years.

Table 3. Two-year means for emergence score, stand count, plant height, and dry-matter yield for various comparisons.

\begin{tabular}{|c|c|c|c|c|c|c|}
\hline \multirow{2}{*}{$\begin{array}{l}\text { Time of } \\
\text { seeding }\end{array}$} & \multirow[b]{2}{*}{ Comparison } & \multirow{2}{*}{$\begin{array}{c}\begin{array}{c}\text { Emergence } \\
\text { score }\end{array} \\
\end{array}$} & \multirow{2}{*}{$\begin{array}{l}\text { Stand } \\
\text { count }\end{array}$} & \multirow[b]{2}{*}{ Plant ht ${ }^{\dagger}$} & \multicolumn{2}{|c|}{ DM yield } \\
\hline & & & & & $\overline{\text { Tops }}$ & Roots \\
\hline & & & plants/plot & $\overline{\mathrm{cm}}$ & $\mathrm{mg} /$ & lant \\
\hline \multirow[t]{19}{*}{ Spring } & Companion crop & & & & & \\
\hline & None & 1. 97 & 179 & 18.7 & 475 & 72 \\
\hline & Oats & 1.94 & 160 & 12.9 & 22 & 3 \\
\hline & L. S. D. 0.01 & $\mathrm{~ns}$ & 10 & 1.2 & 72 & 13 \\
\hline & Variety & & & & & \\
\hline & Madrid & 2.47 & 105 & 13.5 & 221 & 29 \\
\hline & $\mathrm{N} 13$ & 1. 44 & 234 & 18.0 & 276 & 47 \\
\hline & L. S. D. 0.01 & 0.11 & 8 & 0.8 & 43 & 9 \\
\hline & $\underline{\text { Seed size }}$ & & & & & \\
\hline & Small & 2. 34 & 153 & 13.9 & 202 & 30 \\
\hline & Medium & 1. 83 & 185 & 16.2 & 249 & 38 \\
\hline & Large & 1.69 & 170 & 17.1 & 294 & 45 \\
\hline & L. S. D. 0.01 & 0.13 & 6 & $0 . \overline{6}$ & 26 & 5 \\
\hline & Planting depth, $\mathrm{mm}$ & & & & & \\
\hline & 19 & 1,80 & 238 & 16.1 & 229 & 34 \\
\hline & 38 & 1.88 & 165 & 16.3 & 261 & 40 \\
\hline & 57 & $\begin{array}{l}1.00 \\
2.19\end{array}$ & 104 & 14.9 & 255 & 39 \\
\hline & L. S. D. 0.05 & 0.10 & 6 & 0.5 & 23 & 5 \\
\hline & L. S. D. 0.01 & 0.13 & 8 & 0.6 & 31 & 7 \\
\hline \multirow[t]{15}{*}{ Fall } & Variety & & & & & \\
\hline & Madrid & & 100 & & 344 & 160 \\
\hline & N13 & & 144 & & 402 & 313 \\
\hline & L. S. D. 0.01 & & 10 & & 58 & 57 \\
\hline & Seed size & & & & & \\
\hline & Small & & 87 & & 312 & 186 \\
\hline & Medium & & 141 & & 372 & 236 \\
\hline & Large & & 139 & & 435 & 286 \\
\hline & L. S. D. 0.05 & & 9 & & 52 & 31 \\
\hline & L. S. D. 0.01 & & 12 & & 69 & 41 \\
\hline & Planting depth, $\mathrm{mm}$ & & & & & \\
\hline & 19 & & 188 & & 345 & 216 \\
\hline & 38 & & 127 & & 394 & 244 \\
\hline & 57 & & 53 & & 380 & 249 \\
\hline & L. S. D. 0.01 & & 17 & & $\mathrm{~ns}$ & ns \\
\hline
\end{tabular}

"Scoring system for emergence: 1 = fastest to emerge, to 3 = slowest to emerge. $\dagger$ Emergence and plant height were not measured for the fall plantings.

$\ddagger$ Mean of two harvests for spring seeding and three harvests for tall seeding. (ranging from about 70 to $90 \%$ ) werc used in adjustment of seeding rates, to provide comparable numbers of viable seeds. In 1960 , a seeding rate of 60 viable seeds/m was used. In 1961, 80 viable seeds $/ m$ were planted for all entries except the small class of Madrid planted at the greatest depth $(57 \mathrm{~mm})$, for which 240 seeds $/ \mathrm{m}$ were planted in an attempt to obtain sufficient plants.

A V-belt hand seeder was used for planting at depths of 19 , 38, and $57 \mathrm{~mm}$. Each row was raked level after seeding, to assure uniform planting depth. One-row plots were used, with a spacing of $0.91 \mathrm{~m}$ between plots (rows). Row lengths were $5.5 \mathrm{~m}$ in 1960 and $6.7 \mathrm{~m}$ in 1961 .

In both years, spring plantings were made with and without a companion crop. The companion crop, 'Nemaha' oats (Avena sativa L.), was seeded at a rate of $36 \mathrm{~kg} / \mathrm{ha}$ with a grain drill, at right angles to the direction of the sweetclover rows. In 1960, oats was planted 6 days before the sweetclover; in 1961, the interval was 15 days before the sweetclover.

All plantings were made on a Sharpsburg silty clay loam soil at the Agronomy Farm, Lincoln, Neb.

Collection of Data. For the spring seeding in each year, the entries were scored on a 3-point scale for speed of emergence 1 or 2 weeks after planting. Entries that emerged most rapidly were assigned a score of 1 , and those that emerged most slowly were given a score of 3. Subsequently, seedlings werc counted, and plant height (one apparently representative plant per plot) and dry matter production were measured. Only stand counts and dry matter production were mcasured for the fall seedings. To measure dry matter production, three harvests were made at intervals of 2 wecks. In 1960 , each harvest consisted of 10 plants/row. The point at which harvesting was to start in each row was sclecterl at random, and from that point, the next 10 plants were dug in order. Roots of the harvested plants were washed, and tops and roots were separated, dried, and weighed. In 1961, each harvest consisted of 50 plants/row, except that in rows with poor stands, approximately onc-thind of the plants in the row were dug at each harvest. Actual dates of planting and data collection are summarized in Table 2.

Experimental Design. For the spring seedings, a split-splitsplit-split plot design was used, with four replications. The comparisons assigned to the four splits were as follows: first oats vs. no companion crop; second - Madrid vs. N13; third three seed sizes; and fourth - threc planting depths. The design for the fall scedings was similar to that for the spring except that the comparison of oats vs no companion crop was not included.

Conventional analysis-of-variance techniques were used in analyzing and interpreting the data.

\section{RESULTS AND DISCUSSION}

The 1960 growing season was more favorable for sweetclover than the 1961 season. However, the trends observed in both years were very smiliar. Accordingly, only the results of the combined analysis of both years' data are presented here. Overall means and L.S.D. values are presented in Table 3 .

In the comparison of oats vs. no oats, the companion crop had no appreciable effect on emergence score, but it reduced stand count and plant height, and was highly detrimental to vigor, as reflected in dry matter yield/plant. Yields of both tops and roots in plántings with oats were less than $5 \%$ as great as yields in the absence of a companion crop.

In the cultivar comparison, $\mathrm{N} 13$ was superior to Madrid in all attributes measured for both spring and fall seedings. As shown in Table 1, seeds of $\mathrm{N} 13$ were appreciably larger than those of Madrid. Although this size difference was confounded with other possible differences between the two cultivars, at least some of the superiority of N13 very likely was due to larger seed size. 
A definite relationship was observed between seed size and seedling vigor as shown by emergence score, seedling height, and yields of tops and roots in the spring seeding. Seed size and yields also were closely related in the fall seeding. In both spring and fall seedings, stand counts from small seeds were significantly less than stand counts from medium or large seeds. For unknown reasons, stand counts from large seeds were either no different from (fall seeding) or significantly lower than (spring seeding) stand counts from the medium seed class.

The most pronounced effect of planting depth was on stand count. Effects on emergence score, plant height, and yields of tops and roots, although statistically significant in the spring seeding, were not large. Depth of planting had much more influence on the ability of seedlings to emerge from the soil than on their performance after emergence.

Among the numerous interactions, the one of greatest practical importance is the two-factor interaction involving the influence of planting depth and seed size on stand count. The combined analyses indicated highly significant values for this interaction in both spring and fall seedings. Examination of the stand count means for the various seed sizes within each planting depth revealed that stand counts from medium and large seeds were greater than counts from small seeds, especially at the 38 and $57-\mathrm{mm}$ planting depths. This ability of seedlings from larger seeds to emerge from greater depths could be extremely important to stand establishment when the moisture supply is limited.

A number of other statistically significant interactions of two or more factors were indicated by the combined analysis of variance. However, graphing of the means involved in many of the two-factor interactions indicated that changes in the magnitude of the differences between means, rather than in the direction of these differences, were involved. Therefore, main effects rather than interactions have been given primary emphasis in this discussion.

This study demonstrated a striking difference between spring and fall seedings with respect to the ratio of dry weight of tops to dry weight of roots. For the overall means shown in Table 3 this ratio varied from 5.9 to 7.6 for spring-seeded plants and from 1.3 to 2.2 for fall-seeded plants. It is true that the values for spring seeding were based on only two harvests whereas those for fall seeding represent three harvests each year, and there was a strong tendency for the top:root ratio to decrease with increasing seedling age. However, when only the first two harvests were considered, top:root ratios for the fall seeding still were considerably less than the values for the spring seeding. Fall seeding thus appears to have been relatively much more favorable for root growth than spring seeding.

The results clearly indicate that large seed size in sweetclover is advantageous for improved stand establishment. The feasibility of breeding for larger seed size would depend on the heritability of this trait. Heritability was not investigated in these experiments. However, large-seeded lines have been established by selection within P.I.178,985 and another introduction, P.I.227,594 (11). Thus, seed size in sweetclover probably is influenced to a considerable degree by genotype, and good progress in breeding for large seed size could be expected.

\section{LITERATURE CITED}

1. Ahmed, S. U., and M. I. Zuberi. 1973. Effects of seed size on yield and some of its components in rapeseed, Brassica campestris L. var. Toria. Crop Sci. 13:119-120.

2. Black, J. N. 1959. Seed size in herbage legumes. Herbage Abstr. 29:235-241.

3. Burris, I. S., O. T. Edje, and A. H. Wahab. 1973. Effects of seed size on seedling performance in soybeans: II. Seedling growth and photosynthesis and field performance. Crop Sci. 13:207-210.

4. Carleton, A. E., and C. S. Cooper. 1972. Sced size effects upon seedling vigor of three forage legumes. Crop Sci. 12: 183-186.

5. Evans, P. S. 1973. Effect of seed size and defoliation at three development stages on root and shoot growth of seedlings of some common pasture species. N. Z. J. Agric. Res. $16: 389-394$.

6. Manglitz, G. R., and H. J. Gorz. 1963. Sources of resistance to the sweetclover aphid in introduced species of Melilotus. USDA-ARS Report 33-86. 8 p. (Mimeo.)

7. Miller, F. G, and L. H. Pammel. 1901. A study on the germination and growth of leguminosae, especially with reference to small and large seed. Iowa Agric. Coll. Exp. Stn. Bull. 62:155-177.

8. Mytton, L. R. 1973. The effect of seed weight on the early growth and nodulation of white clover. Ann. Appl. Biol. 73:329-338.

9. Ries, S. K., and E. H. Everson. 1973. Protein content and seed size relationships with secdling vigor of wheat cultivars. Agron. J. 65:884-886.

10. Robinson, R. G. 1974. Sunflower performance relative to size and weight of achenes planted. Crop Sci. 14:616-618.

11. Smith, W. K., and H. J. Gorz. 1965. Swectclover improve ment. Adv. Agron. 17:163-231.

12. Townsend, C. E. 1972. Influence of seed size and depth of planting on seedling emergence of two milkvetch species. Agron. J. 64:627-630.

13. Twamley, B. E. 1974. Recurrent selection for seedling vigor in birdsfoot trefoil. Crop Sci. 14:87-90.

14. Zavitz, C. A. 1908. The relation between the size of seeds and the yield of plants of farm crops. Proc. Am. Soc. Agron. $1: 98-104$. 